Goldschmidt 2021 Abstract

https://doi.org/10.7185/gold2021.5985

\section{Boron isotope variations in tourmaline from hydrothermal ore deposits: controlling factors and insights for mineralizing systems}

\author{
ROBERT B TRUMBULL ${ }^{1}$, MARTA S. CODEÇO ${ }^{1}$, SHAO- \\ YONG JIANG $^{2}$, MARTIN R. PALMER ${ }^{3}$ AND JOHN F. \\ $\mathrm{SLACK}^{4,5}$ \\ ${ }^{1}$ GFZ German Research Centre for Geosciences \\ ${ }^{2}$ China University of Geosciences \\ ${ }^{3}$ School of Ocean and Earth Sciences, University of \\ Southampton \\ ${ }^{4}$ United States Geological Survey (emeritus) \\ ${ }^{5}$ Dept. of Earth Sciences, Memorial University of Newfoundland \\ Presenting Author: bobby@gfz-potsdam.de
}

Boron is a fluid-mobile element whose isotopic composition reflects many factors that are relevant to understanding mineralizing processes, including fluid source(s), fluid-rock interaction, and mineralization temperature. The most important host of boron in hydrothermal mineral deposits is tourmaline, which is fortuitous because this is a very stable and chemically resistant mineral with a wide compositional range.

We have compiled published B-isotope data of tourmaline from 110 hydrothermal deposits worldwide ( $>2210$ analyses) organized into seven groups: porphyry $\mathrm{Cu}-\mathrm{Mo}-\mathrm{Au}$ deposits, granite-related Sn-W deposits, IOCG deposits, orogenic Au deposits, stratabound VMS and SEDEX deposits, and sedimenthosted U deposits (Mendeley Data, V4, doi: 10.17632/tv5y7xt9fb.4).

The total range of $\delta^{11} \mathrm{~B}$ values for all deposits is -26.8 to +35.0 $\%$. Four deposit types (granite $\mathrm{Sn}-\mathrm{W}$, orogenic $\mathrm{Au}$, stratabound VMS and SEDEX) have median $\delta^{11} \mathrm{~B}$ values close to the continental crustal average of ca. $-10 \%$, whereas the median values for IOCG and porphyry $\mathrm{Cu}-\mathrm{Mo}-\mathrm{Au}$ deposits are higher (-3.9\%o and $-2.1 \%$, respectively); the median for sedimenthosted $U$ deposits is distinctly higher (+25.3\%). Importantly, each deposit type displays a considerable range of $\delta^{11} \mathrm{~B}$ values, the smallest being $18 \%$ for granite Sn-W deposits and the largest (48 \%) for IOCG deposits.

These boron isotope ranges are suggested to reflect three levels of controlling factors. The primary one is the composition of the boron source; secondary effects relate to fluid-tourmaline fractionation (equilibrium or Rayleigh). There are commonly also tertiary factors that depend on evolution of the specific deposit, which include fluid mixing, changing water-rock ratio and/or depositional temperature, influences of other boronbearing minerals, and where relevant, post-ore metamorphism. Separating the effects of these factors is rarely possible from boron isotopes alone, as selected case studies illustrate. However, multi-isotope studies of tourmaline, and approaches that combine isotopic and chemical variations in tourmaline can potentially overcome this limitation.

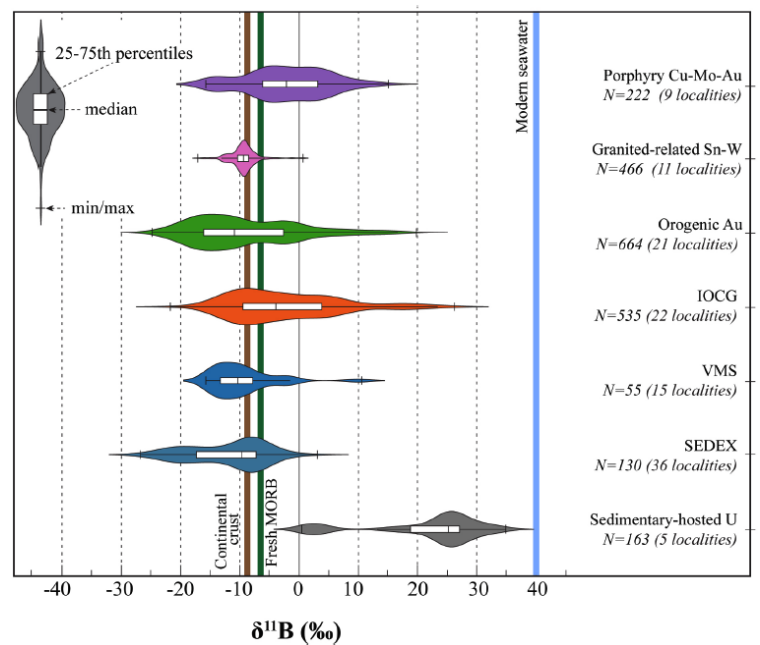

$\delta^{11}$ B (\%o) 